\title{
INTEGRATION OF THE COMMUNITIES IN THE AREAS UNDER LARGE IRRIGATION PROJECTS IN AFRICA
}

Construction of large dams has aroused much debate among its advocates and opponents. The most debatable issue is the impact of large irrigation schemes on the physical environment. Their impact on man is rarely discussed as it is difficult to assess in economic terms such human emotions as stress, the sense of lack of stabilization, or psychic discomfort. On the other hand, their perception is extremely subjective.

This paper is an attempt to systematize the data on this subject from scarce materials published in the 1970 s, that is at a time when there was an increased interest in this problem in Africa. Later on, the longer was the period of the functioning of large dams in Africa (High Aswan Dam, King, Akosombo, Kariba, Kafue, Gezira), the less time and money were spent to trace their impacts on natural and human environment. Hence the absence of comprehensive research in the subsequent years.

Migrations of population caused by the construction of large dams stemmed from: (1) compulsory displacement of the population (being, as a rule, members of one tribe) from the areas in which a construction of an artificial lake was planned; it usually occurred in the regions of construction of large dams (Aswan, Akosombo, Kainji, Kariba, Kossou etc.); (2) the resettlement of the population (of different ethnic background) on newly reclaimed and artificially irrigated agricultural land; voluntary settlement is always accompanied by compulsory displacement but it is usually the basis for many irrigation projects. Voluntary resettlement was admitted in the areas of the project of "North-Western Delta of the Nile", projects in Marsa Matruh and the north-western part of the Sinai peninsula (Egypt), and partly the Gezira scheme in the Sudan.

Thus, a new territorial community consists of three groups of people:

(1) newcomers who were forced to resettle there;

(2) newcomers who came here voluntarily seeking new life chances;

(3) the indigenous population who is compelled to receive migrants.

According to the place of construction of new settlements, the third group (i.e. the hosts) is larger or smaller. There are irrigation projects 
where new villages (or even towns) were built in a previously inhabited area, where the system of artificial irrigation was introduced or developed (e.g. in Upper and Middle Egypt). At the same time, some projects caused that new settlements were established in empty areas, e.g. an abortive resettlement of the Tonga people, under the Kariba project, to the areas of occurrence of the tsetse fly.

The reason why people migrate to new areas is essential for achieving success in creating irrigation projects. If it is a compulsory resettlement, the new community is usually reluctant beforehand. Unfortunately, in many a case this reluctance is justified. As a result of construction of an artificial lake the population living in the river walley for many generations and using its fertile alluvial soils or involved in fishery is resettled onto worse land, situated farther from the river and sometimes even unprepared for cultivation. It often turns out, after the new land has been managed, that the household assigned to a family is smaller than that left in the place of origin. In this case the living standard of the population is decreasing. This was the case of many irrigation schemes, including the area of the "Upper Volta Project", in New Nubia or in the region of the Kariba Dam (the Tonga people). Financial compensation which is sometimes offered is rarely adequate to the value of the households left behind. It happens that people quickly spend the money before they have the opportunity to buy a new land, another house etc. (Barrow 1987). The newly settled houses in new villages are often disapproved by their inhabitants. They often differ in size, appearance, building material and functional character from the traditional houses of a given tribe. The Nubians in New Nubia in Egypt suffer in identical low, concrete box-like houses, since their own ones in Old Nubia were large, had plenty of room and were adjusted to climate (cool in summer and warm in winter), with a decorated front wall and a bench at the entrance. The bench was the place of traditional meetings and talks needed to keep social ties (Fahim 1981). The inhabitants of the project of the "North- Western Delta of the Nile" are dissatisfied to have their houses considerably distant from farm buildings (though the reason for this decision was basically rightful - separation of livestock from the people, which was meant to be convenient and hygienic. In effect, the animals stay in the houses, where their proprietors have them under their constant care while farm buildings serve as dwellings for part of the rapidly growing family (Tadros 1978).

The voluntary settlers in the newly established agricultural areas are mostly small-holders or landless peasants. In a few cases these are settlers from the areas of military conflict or ecological disaster. A certain small group consists of those who live on non-agricultural professions, that is teachers, medical staff, smiths, potters, barbers, tailors etc. In many a case, by settling in a new place, they hope for success and better chances, However, there arise problems associated with their young age, since the 
migrants include mainly young men. After some time, they often feel lost in a new reality. They feel that they lack knowledge and authority of the elders and face serious difficulties in setting up a family. These facts. coupled with over-population in the given areas and tribal conflicts (the young ones being very quick-tempered), seriously affect the minds, and the ensuing physical health of the settlers (MAB 1976; Man-made... 1972; Tadros 1978). These problems occurred in the case of many Egyptian projects.

Also the native population, which must accept migrants, finds it difficult to approve new conditions even if they are promised to have better living conditions as the artificial irrigation proceeds. The main problems are bound up with the increasing overpopulation and ethnic conflicts. The original inhabitants feel no longer the hosts of their villages, particularly if under new conditions they constitute ethnic minority. Especially complicated was the situation at Khashm el-Girba (New Halfa) in the Sudan, where the government decided to settle three ethnic groups on one territory: the tribes of Shukyra and Beja (traditionally engaged in shepherding; half of the population was forced by the government to turn to a sedentary life) and Halfians (i.e. inhabitants of the former Halfa in the Nile valley, traditional agriculturists). The Halfians find nomads to be "aggressive and dishonest", while nomads treat the Halfians as "intruders" who came onto their old territory. So they cannot understand why they are not allowed to graze their sheep on lands presently cultivated by the Halfians (even though they had been bought by the government). Besides, nomads are dissatisfied with their housing conditions, because they continue to live in traditional mud-and-wattle huts, whereas the newcomers (Halfians) have been given new modern houses. The Halfians, on the other hand, are deeply disappointed both with their new houses and new arable land, as well as with the neighbourhood (Goldsmith, Hildyard 1984).

In the case of many large irrigation projects we can observe groups of problems which equally concern forced settlers and voluntary newcomers. These are the following problems:

(1) problems with local governments, change of authority and distribution of income;

(2) changes in techniques of labour, its distribution, development of market economy etc.;

(3) changes of social order, lifestyles, new contacts and influences etc.

Problems with local authorities are many-sided. In the case of large irrigation projects local authority is exercised by the people who do not belong to the community living in the given area. As a rule, they have been enforced by governmental institutions, disregarding people who enjoy authority or tribal leaders. Therefore, the land is not divided according to the traditional law, water regulations function in a different way, and different crops are introduced (beside traditional food crops sunflowers are 
grown for oil or a wide variety of vegetables if there is a remarkable market nearby). Sometimes, the local authorities, being often unqualified, are fond of manifesting their dominance (for example, in the case of the project of the "North-Western Delta of the Nile") (Man-made... 1972; Tadros 1978).

Numerous problems stem from the change in labour techniques. Many migrants come from the regions of different natural conditions than the present ones. For example, in artificially irrigated areas in the arid and semi-arid zone there settle peasants both from more humid rainfed areas, and the former nomads. Under new conditions, they make many mistakes in land cultivation. For example, the Tonga people, which used to cultivate fertile alluvial soils on the river banks, when moved to new land, faced serious difficulties in the understanding of the rules of crop rotation, ferilizing and protection of soils from erosion (Goldsmith, Hildyard 1984).

Artificial irrigation entails increasing obligations as there is more work to do than it used to be (crops are harvested several times in a year), and the quality requirements are growing (new cultivation methods, agricultural machines, artificial fertilizers etc.). At the same time, leisure time is shrinking which weakens traditional social ties and makes it difficult to form the new territorial community. If approached in a different way, this phenomenon has positive aspects, too. If the given area is developing in accordance with the expectations of planners, the increasing amount of crops is earmarked for sale. As the commodity economy develops, the peasants must cope with new exigencies. They must learn the fundamentals of economics (costs, net and gross profit, principles of marketing and crediting), skilful use of mechanization, introduction of proper soil fertilization and means of plant protection. Education of children, closer contacts with the world and the ensuing openness for changes, appear to be important. Thus the lifestyle and living standard of the family, as well as its hierarchy of values are changing. All these changes may lead to increased integration of the new community and a higher level of its development (MAB 1976; Man-made... 1972).

A widespread and practically insoluble problem is the lack of solidarity among the new neighbours. This solidarity is necessary to organize formal groups in order to obtain credits in the bank, protect crops or take care of the canals or irrigation ditches. A real authority without which the new community cannot function as a whole is clearly lacking.

As the above-mentioned examples show, the success in constructing a large irrigation programme is basically dependent on the way of settlement in the areas brought under cultivation. The character of the resettlement (compulsory or voluntary) determines people's perception of new reality, as well as their enthusiasm for work. Compulsory displacement of population groups is the most controversial aspect of the establishment of large irrigation projects. Of great importance is also the type of land tenure (proprietors are usually more devoted to work than tenants) as well as the 
degree of wealth. In many countries the settlers on newly reclaimed agricultural land are chosen from among the poorest landless peasants and, according to the results of the fieldwork (Tadros 1978), those with relatively higher income are more inclined to approve of any changes and success.

\section{REFERENCES}

Barrow M.HG., 1987, Water resources and agricultural development in the tropics, New York.

F a hi m M.H., 1981, Dams, people and development, Pergamon Press.

Goldsmith E., Hildyard N., 1984, The social and environmental effects of large dams, Vol. 1, ECOROPA.

MAB, 1976, Programme on man and the biosphere, Final Report, UNESCO.

Man-made lakes as modified ecosystems, 1972, SCOPE Report 2, Paris.

Tadros H.R., 1978, "Rural resettlement in Egypt's reclaimed lands", Cairo papers in social science, Vol. 1, American University in Cairo. 
